\title{
De Boulainvilliers a Tocqueville: da liberdade como defesa de privilégios à liberdade como defesa de diferenças
}

\section{Resumo}

Desde meados da segunda metade do século XX, parte expressiva do pensamento social e político vem conferindo destaque à obra de Alexis de Tocqueville. Nesta etapa, sua reflexão é revista nos marcos da democracia liberal: haveria em sua abordagem preciosas sugestões quanto aos dilemas das democracias modernas. Tal percepção, porém, pressupõe certo nexo entre os conceitos de liberalismo e democracia distante do universo intelectual próprio às preocupações tocquevillianas. Pretende-se, neste artigo, apontar o viés conservador subjacente às análises de Tocqueville. Para tanto, sua obra será interpretada à luz da tradição liberal francesa na qual ela se insere, e que remonta à Querela das duas raças, protagonizada por Henri de Boulainvilliers no crepúsculo do século XVII. Trata-se da gênese de uma tripla polaridade que informa Tocqueville: em um eixo positivo, liberdade, heterogeneidade e descentralização; no negativo, igualdade, homogeneidade e centralização.

Palavras-chave: Pensamento conservador. Democracia. Germanismo. Século XIX. Liberalismo.

\footnotetext{
"Professora do Departamento de Sociologia do Instituto de Filosofia e Ciências Sociais da Universidade Federal do Rio de Janeiro (Brasil). E-mail: gahyva@superig.com.br
} 


\section{From Boulainvilliers to Tocqueville: from freedom as defense of privilege to freedom as defense of differences}

\section{Abstract}

From the second half of the 20th century on, several social and political writers have turned their attention to Alexis de Tocqueville's work. By doing that, these writers re-read Tocqueville from the perspective of liberal democracy. The basic assumption was that there was, in his approach, precious clues for the understanding of modern democracy dilemmas. This perception, though, supposes some nexus between the concepts of liberalism and democracy which is far from Tocquevillian intellectual scenery. In this article, I intend to identify the conservative bias inherent to Tocquevillian analysis. In this sense, his work will be interpreted in the light of French liberal tradition, in which it is located. It must be added that this tradition is connected to the two races quarrel, as defined by Henri de Boulainvilliers in the end of 17th century. It deals with the genesis of a triple polarity in Tocqueville's work: in a positive axis, liberty, heterogeneity and decentralization; in a negative one, equality, homogeneity and centralization.

Key words: Conservative thought. Democracy. Germanism. 19th century. Liberalism.

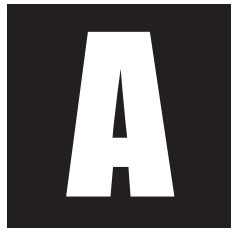

lexis de Tocqueville (1805-1859) destacou-se no cenário social e político francês do século XIX tanto pela repercussão de suas principais obras - tal como atesta, por exemplo, o sucesso do primeiro volume de $A$ democracia na América (1835) -, como por sua atuação na vida política, cujo ápice corresponde à sua breve passagem pelo Ministério dos Negócios Estrangeiros, em 1849. Durante a primeira metade da centúria passada, todavia, as reflexões de Tocqueville sofreram certo eclipse. Em um primeiro instante, a crise da ideologia liberal parecia le- 
gar ao ostracismo alguns de seus principais representantes (Hobsbawn, 2000; Mazower, 2001). Finda a Segunda Guerra Mundial, a supremacia do modelo welfarista em parte significativa das democracias ocidentais privilegiava teorias nas quais ao Estado cabia organizar a contingência (Santos, 1997, p. 76-79). Paralelamente, a alternativa comunista conduzia setores da intelectualidade à identificação com propostas que buscassem a superação do modo capitalista de produção. Mas, à crise de paradigmas que começou a se configurar nos anos 1960, e que se concretizou com o fim da Guerra Fria, intensificou-se o interesse por teorizações que, grosso modo, questionassem determinados rumos das democracias liberais sem desprezar seus princípios fundamentais. Observa-se, a partir de então, crescente dedicação à obra de Tocqueville (Furet, 1991, p. 138; Rodriguez, 1999, p. 131): suas ideias têm sido retomadas na expectativa de fornecer indicações quanto às encruzilhadas características das democracias modernas. Assim, o escritor francês chegou ao século XXI como uma espécie de baluarte da democracia liberal.

Esta apreciação, contudo, pressupõe certo nexo entre os conceitos de liberalismo e democracia, distante do universo intelectual próprio às preocupações tocquevillianas, marcado pela aproximação que ora se fazia entre democracia e poder proletário (Reis Filho, 1998, p. 86). Em outros termos, seu pensamento é contemporâneo a uma época, na qual os conceitos de liberalismo e democracia são antitéticos.

Tendo como pano de fundo essa oposição, o objetivo deste trabaIho consiste em apontar certo viés conservador subjacente às análises de Tocqueville. Para tanto, suas reflexões são vistas à luz da tradição liberal francesa que remonta à ideologia germanista desenvolvida durante a Querela das duas raças, polêmica protagonizada pelo conde Henri de Boulainvilliers, no crepúsculo do século XVII e meados do XVIII. Trata-se de identificar a gênese de uma tripla polaridade que informa a perspec- 
tiva tocquevilliana: em um eixo positivo, liberdade, heterogeneidade e descentralização; no eixo negativo, igualdade, homogeneidade e centralização. Seguindo a orientação de Lucien Goldmann, sugere-se que essa tradição contribuiu para limitar a esfera de consciência possível (Goldmann, 1986, p. 52) de Tocqueville em suas tentativas de compreender o surgimento e os rumos da nova ordem igualitária que vira emergir.

Com o objetivo de fazer frente às pretensões reais, Boulainvilliers inaugurou a Querela resgatando a interpretação que François Hotman construíra em Franco-Gallia (1574). Este teórico protestante francês recorria às presumidas origens germânicas de seu povo na expectativa de refutar suas relações ancestrais com a romanidade. Sua reflexão inseria-se no movimento de oposição à Contra-Reforma. Àquela hora, reivindicar aos seus uma origem germânica significava vincular a França da segunda metade do século XVI ao movimento reformador, tipicamente alemão (Febvre, 1999).

Boulainvilliers reescreveu a dualidade entre romanidade e germanidade nos momentos finais de consolidação da monarquia nacional francesa: a ascendência germânica e as prerrogativas dela derivadas tornavam-se patrimônio exclusivo da aristocracia. Esta sugestão inaugurou uma linha de reflexão que justificava - e reforçava - historicamente as afinidades entre os elementos de extração nobre. Ou seja, por meio do nobre litigante ilustrase o modo como determinados setores da nobreza reagiram ao processo de formação da monarquia absoluta. Em reação à crescente centralização, parteira do Estado-Nação francês, eles buscaram nos recônditos da história francesa os fundamentos para a manutenção dos privilégios ora ameaçados, construindo uma noção de despotismo que se encontra na gênese do liberalismo francês (Henshall, 1992). Neste embate, eles cindiram a nacionalidade em seu momento de afirmação: as pretensões reais feriam a soberania de uma nação com leis próprias - a nobreza. 
Para Tocqueville, a expansão do estado social democrático é a característica distintiva da experiência moderna. Na qualidade de valor definidor da modernidade, a igualdade não corre riscos - ela é universal, duradoura e escapa crescentemente ao poder humano (Tocqueville, 1998, p. 11). A liberdade, por outro lado, torna-se valor fugaz, constantemente sujeito a ameaças. Por isso, apesar ter denominado sua mais famosa obra A democracia na América, as preocupações de Tocqueville voltavam-se para a liberdade. Se as democracias caracterizavam-se pela igualdade de condições, a liberdade, para ele, seria propriedade das sociedades aristocráticas. A questão chave para a qual se orientavam suas preocupações versava sobre a possibilidade de reatualização dessa qualidade aristocrática - a liberdade - em um contexto igualitário.

No mundo aristocrático, cria ele, os corpos intermediários preservavam a liberdade. Funcionando como filtros entre os súditos e o soberano, eles garantiam os dois pré-requisitos que, para Tocqueville, asseguravam a liberdade: a participação política e o pluralismo. Esses poderes secundários representavam arenas locais de debate nas quais os indivíduos aptos a participar da vida pública faziam valer os hábitos e costumes provinciais. Em outras palavras, eles preservavam as diferenças em face da tendência homogeneizadora própria à potência real.

Ao robusto sentimento de hierarquia que contribuía para a estabilidade das sociedades aristocrática sucedeu-se, com o advento da democracia, a aceleração daquela caminhada, iniciada há aproximadamente sete séculos, rumo ao nivelamento universal (Tocqueville, 1998, p. 9). Os ventos modernos desqualificaram a noção segundo a qual cada um ocupava lugar fixo na estrutura social. As distâncias sociais, agora, seguem a lógica precária, pois que potencialmente provisória, da mobilidade social. Nesse novo arranjo, assegura-nos Tocqueville, 
[...] todos os extremos se atenuam e se embotam; quase todos os pontos salientes se apagam para ceder lugar a algo médio, que é ao mesmo tempo menos elevado e menos baixo, menos brilhante e menos obscuro do que o que se via no mundo (Tocqueville, 2000, p. 406).

O espanto que lhe provoca a nova massa de homens médios e iguais constitui o leitmotiv das reflexões tocquevillianas.

Em sociedades de fortunas móveis e instáveis, compostas por indivíduos orientados pela moderna ética do trabalho, os valores da liberdade tendem a sucumbir em face da crescente mercantilização das relações sociais. O perigo, para ele, brota das entranhas das democracias: a vocação cívica dos indivíduos arrefece quando eles abandonam as questões de natureza pública em função de preocupações excessivas com seus interesses privados. Segundo Tocqueville:

Quando o gosto pelas fruições materiais se desenvolve num desses povos [democráticos] mais rapidamente do que as luzes e os hábitos da liberdade, chega um momento em que os homens ficam arrebatados e como que fora de si, ao verem esses novos bens de que estão prestes a se apoderar. Preocupados unicamente com fazer fortuna, não percebem mais o vínculo estreito que une a fortuna particular de cada um deles a prosperidade de todos. O exercício de seus deveres políticos thes parece um contratempo incômodo que os distrai de sua indústria. [...] Essa gente crê seguir a doutrina do interesse, mas só têm dela uma idéia grosseira e, para zelar melhor pelo que chamam seus negócios, negligenciam o principal, que é permanecer donos de si mesmos (Tocqueville, 2000, p. 172).

Quando os homens democráticos renunciam à participação política, alongam-se os tentáculos da centralização administrativa. A liberdade vêse abatida por um inimigo fatal: o despotismo democrático. A junção destas duas ideias historicamente antagônicas - despotismo e democracia - tem como objetivo diferenciar a nova forma de submissão daquelas 
configurações despóticas "tradicionais" (Bobbio, 1991, p. 340; Vollrath, 1986, p. 132). Não é o medo, mas o consentimento dos cidadãos que origina o moderno despotismo. Ele pressupõe o direito às franquias democráticas e, se entra em cena, é porque os indivíduos abrem mão de seu papel decisório nas arengas públicas. Em troca, exigem do Estado crescentemente centralizador - e não poderia ser diferente! - tranquilidade social. O individualismo egoísta é o parteiro do despotismo democrático, dirigindo a atenção dos homens democráticos à sua restrita esfera privada ${ }^{1}$.

Não é possível compreender o novo cenário histórico, no qual a noção de direito comum substitui a de privilégio (Furet, 1988, p. 181), com olhos de outrora. Tocqueville demanda a criação de uma nova ciência para um mundo inteiramente novo (Tocqueville, 1998, p. 12). Este urgente desafio envolve simultaneamente o diagnóstico do presente e as apostas para o futuro. Trata-se de estabelecer sob quais condições a inevitável igualdade permite a coexistência de seu contrário, a liberdade. Em outros termos, ainda que, segundo ele, igualdade e liberdade tenham caminhado frequentemente em oposição histórica, Tocqueville impôs-se como tarefa investigar as possibilidades de suavizar tal polaridade. À vista da alternativa, o desafio adquire ares de missão: igualdade sem liberdade se transforma, necessariamente, em servidão, pois

Só a liberdade é capaz de arrancá-los [os homens democráticos] ao culto do dinheiro e aos pequenos aborrecimentos coti-

\footnotetext{
${ }^{1}$ Em "O Antigo Regime e a Revolução", Tocqueville reafirma sua convicção quanto às perigosas conexões entre centralização, individualismo e despotismo: Não havendo mais entre os homens nenhum laço de castas, classes, corporações, família, ficam por demais propensos a só se preocuparem com seus interesses particulares, a só pensar neles próprios e a refugiar-se num estreito individualismo que abafa qualquer virtude cívica. Longe de lutar contra esta tendência, o despotismo acaba tornando-a irresistível, pois retira dos cidadãos qualquer paixão comum, qualquer necessidade mútua, qualquer vontade de um entendimento comum, qualquer oportunidade de ações em conjunto, enclausurando-se, por assim dizer, na vida privada. Já tinham a tendência de separar-se: ele os isola; já havia frieza entre eles, ele os gela (Tocqueville, 1979, p. 46).
} 
dianos de seus negócios particulares para que percebam e sintam sem cessar a pátria acima e ao lado deles. Só a liberdade substitui vez ou outra o amor do bem-estar por paixões mais enérgicas e elevadas, fornece à ambição objetivos maiores que a aquisição de riquezas e cria a luz que permite enxergar os vícios e as virtudes dos homens (Tocqueville, 1979, p. 47).

Assim, caberia à nova ciência identificar instrumentos que pudessem, se não neutralizar, ao menos contrabalançar o espírito excessivamente individualista que ameaça as democracias. Ela deveria revelar mecanismos capazes de transcender aquela percepção negativa da liberdade (Berlin, 1981, p. 136-142) na qual o exercício intermitente dos direitos políticos praticamente esgota o raio da participação política da franca maioria dos homens modernos. Suas esperanças no mundo democrático envolvem constante e intenso diálogo entre liberdade, participação política e, consequentemente, preservação de diferenças, por isso a opção ao estreito círculo de virtuosos de outrora precisa ser mais robusta do que a mera segurança dos privilégios privados (Constant, 1985, p. 16). Contentar-se com o binômio delegação/representação é próprio aos iguais submersos na servidão.

Mas a democracia, se aliada à descentralização administrativa, talvez pudesse superar o impasse. Foi o que Ihe sugeriu sua estadia norteamericana. Lá Tocqueville identificou uma sociedade na qual a igualdade não obliterava uma intensa vida associativa. Ou seja, se as paixões democráticas poderiam conduzir à apatia pública, o associativismo reinseria cotidianamente a virtude cívica nos espíritos dos norte-americanos, e o individualismo egoísta convertia-se em interesse bem compreendido. Se, como se sugeriu mais acima, Tocqueville bradava pela necessidade de reatualização, em bases democráticas, daqueles corpos intermediários que asseguravam a vigência da liberdade nas sociedades aristocráticas, o contato com o associativismo norte-americano fortaleceu sua convicção quanto às estreitas conexões entre descentralização administrativa e 
liberdade. Destinar aos cidadãos a responsabilidade pela administração das questões locais estimulava a prática associativa e, consequentemente, a interdependência individual, de modo que era por meio da harmonia do conjunto da sociedade que cada cidadão obtinha segurança na consecução de suas metas².

A liberdade, porém, não se esgota na participação política. Ela não se realiza, por exemplo, quando pautada por consensos majoritários. A participação dos cidadãos na vida pública somente engendra liberdade quando preserva as diferenças, isto é, quando garante o pluralismo. Mais uma vez, o associativismo norte-americano parecia vencer outro rival impiedoso da liberdade: a tirania da maioria. Os yankees reescreveram o associativismo - em realidade, eles praticavam o multiassociativismo. Desde os Artigos Federalistas, afinal, a república americana fora incensada com a convicção de que o facciosismo garantiria a liberdade (MADISON, HAMILTON; JAY, 1993, p. 169-192). A existência de múltiplas associações de interesses permitiria que as minorias se opusessem a uma provável maioria opressiva. Ou seja, na América, essa experiência quimicamente pura de democracia (Furet, 1982, p. 223), as forças niveladoras características da igualdade eram relativamente contrabalançadas por uma prática associativista na qual a liberdade, como outrora nas sociedades aristocráticas, promovia as diferenças.

Contudo, as apostas de Tocqueville quanto à permanência da liberdade nas sociedades democráticas tornam-se cada vez mais pascalinas. $\mathrm{O}$ acirramento de sua verve pessimista é visível, como revela tanto o segundo volume de A democracia na América, quanto suas duas obras poste-

\footnotetext{
${ }^{2}$ Verdadeiros 'poderes intermediários' [...], as associações resumem o combate que Tocqueville trava pela liberdade política: elas constituem verdadeiramente o antídoto ao individualismo a corrigir a fraqueza e a sacudir a apatia do cidadão atomizado; elas educam para a via pública, oferecendo oportunidade de articular o interesse privado com o' interesse público' (Besnier, 1990, p. 76).
} 
riores, O Antigo Regime e a Revolução e Lembranças de 1848. Subjazem aos seus temores, simultaneamente, uma concepção de liberdade que, a despeito de seus esforços, permanece constitutivamente oposta à de igualdade, e a constatação de sua inadequação paulatina a uma modernidade esmagada entre os extremos da apatia ou da revolução.

\section{III}

Tocqueville já foi apontado como um dos últimos herdeiros da ideologia germanista na França (Aron, 1987, p. 64). Interessa-me, neste trabalho, resgatar o elo entre sua concepção de liberdade e a ideologia germanista própria à reação nobiliárquica que inaugurou a Querela das duas raças - aquele embate teórico político que, entre as décadas finais do século XVII, e as primeiras do XVIII, opôs defensores e críticos à monarquia absoluta - romanistas e germanistas, respectivamente.

Sem quaisquer pretensões de retroceder minuciosamente à longa discussão quanto à gênese do povo francês, intenta-se perceber como, no âmbito da Querela, os opositores da centralização monárquica combateram as ambições romanistas afirmando a incompatibilidade histórica entre as medidas niveladoras postas em cena pela crescente potência real e as supostas origens germânicas - superiores e exclusivas - da aristocracia francesa (Meinecke, 1982, p. 148).

O conde Henri de Boulainvilliers foi o porta-voz da posição germanista (Foucault, 2002, p. 172; Furet; Ozouf, 1989, p. 702). Ele escreveu Histoire de l'Ancien Gouvernement de la France - obra que circulou clandestinamente em fins do reinado de Luís XIV, mas que só foi publicada em 1727 (Jardin, 1989, p. 18) - com o objetivo de se opor à versão da história francesa produzida pelos intendentes das províncias em Mémoires des Généralités du Royaume. Na perspectiva do nobre litigante, ao conferir 
aos franceses uma origem romana comum, eles corroboravam a reivindicação real ao poder absoluto, pois seria o soberano descendente direto do Império Romano. A narrativa construída pelos intendentes também atribuía ao rei a qualidade de representante da nação como um todo, justificando seu objetivo de não mais se relacionar com a nobreza como primus inter paris (Arendt, 1989, p. 192).

Para Boulainvilliers, as raízes históricas dos privilégios desfrutados pela nobreza francesa remontavam à conquista do país pelos francos (ou germanos). Desaparece em seu relato o mito seiscentista de uma Gália harmônica (Foucault, 2002, p. 173) cuja ordem já sedimentada fora subvertida pela invasão dos germanos. Para o conde Henri, a região corresponderia, na realidade, a uma terra de conquista na qual o direito romano penetrara apenas superficialmente. A população local escapara do sufocante jugo romano graças à ação dos guerreiros francos. Em sua interpretação, a invasão convertia-se em libertação.

A partilha do território entre os membros da aristocracia guerreira, origem da propriedade feudal e de seus correlatos privilégios, fora consequência imediata da vitória franca - um direito de conquista, portanto. Doravante proprietários independentes, os vencedores converteram-se em leudes ${ }^{3}$, casta militar homogeneamente franca. As prerrogativas derivadas dessa condição legitimavam-se socialmente por meio de uma lógica de reciprocidade compartilhada com os camponeses gauleses. Em outras palavras, Boulainvilliers narrava a aurora da organização feudal louvando a estabilidade conquistada por um sistema de contraprestações no qual aos leudes caberiam as decisivas atividades guerreiras, e ao súdito gaulês ficaria reservada a responsabilidade de

\footnotetext{
${ }^{3} \mathrm{O}$ termo designa compatriotas, pessoas de mesma sociedade e condição (Boulainvilliers, 1727, p. 30).
} 
[...] fornecer a seus senhores seu trabalho manual para todos os tipos de obra, e especialmente para a cultura da terra, que era a principal, e da qual os senhores e os súditos deviam tirar sua subsistência, ainda que de modo desigual, pois os primeiros se destinavam a viver na abundância, e os segundos estavam contentes com o necessário, do que eles tinham quase sempre sido privados sob a dominação dos romanos (Boulainvilliers, 1727, p. 47).

Na monarquia eletiva dos leudes, o soberano atuava como rei de dupla conjuntura (Foucault, 2002, p. 181): em momentos de paz comportava-se como magistrado civil; quando submetido aos constrangimentos próprios aos tempos de guerra, assumia poderes absolutos. O nobre querelante reconhece que esse arranjo encontrou brevemente seu termo em função de suas próprias qualidades, pois o rei acabou por aplicar a épocas de relativa tranquilidade aquelas prerrogativas absolutas.

Os membros da aristocracia guerreira tentaram erguer barreiras à ampliação dos poderes do soberano, mas sucumbiram às estratégias reais: tanto a arregimentação de mercenários gauleses, quanto a aliança com elementos da antiga aristocracia, também de origem gaulesa. Estes últimos estavam, desde a derrota para os germanos, refugiados nas fileiras da Igreja, onde mantiveram o Direito Romano. Aliando-se ao rei, tornaram o latim idioma de Estado. A partir daí, assegura-nos Boulainvilliers, os guerreiros francos, isolados em seu sistema linguístico próprio, testemunharam sucessivas usurpações de seus direitos assegurados por meio de conquista (Foucault, 2002, p. 184)

Apresentar, ainda que de forma sucinta, a versão do conde Henri sobre as origens da monarquia francesa revela como, por meio do germanismo, setores da nobreza estabeleceram um vínculo supranacional cujo princípio identitário fundamentava-se na procedência franca. Como consequência, aqueles que partilhavam essa origem, mesmo quando dis- 
persos pelo continente europeu, se tornavam imediatamente próximos, ao mesmo tempo em que afastados da plebe gaulesa. Em outros termos, a reação nobiliárquica inaugurada com a Querela reagiu ao esforço unificador característico da potência real, estabelecendo uma cisão no corpo da nação que terminou por produzir um novo sujeito histórico: a nação.

A suposta contradição decorre de desacerto semântico, pois as duas referências feitas acima à "nação" correspondem a conceitos homônimos, porém diferentes. Trata-se, no primeiro caso, de um corpo de associados que vive sob uma lei comum e representados pela mesma legislatura (Sieyes, 1988, p. 69). Já no segundo, "nação" não é detida no interior das fronteiras mas é, ao contrário, uma espécie de massa de indivíduos móveis de uma fronteira à outra, através dos Estados, sob os Estados, num nível infraestatal (Foucault, 2002, p. 169). Esta é a compreensão típica dos querelantes, construída, em larga medida, em reação ao desenvolvimento histórico da moderna ideia de Estado-nação (Bobbio et al, 1991, p. 795). Neste sentido, à narrativa de Boulainvilliers subjaz um grito em defesa da preservação de sua própria nação, cujos privilégios vinham sendo solapados pela ampliação do raio de ação da potência real.

De um lado, então, ele bradava contra a crescente centralização do poder régio, mas a outra face de sua espada procurava atingir o constante movimento de enobrecimento de indivíduos de origem plebeia. Contra esses dois alvos, argumentos semelhantes com conclusões distintas. O soberano que solapava tentacularmente a autonomia e a diversidade provinciais usurpava aquelas leis fundamentais do reino que, derivadas de um direito de conquista, asseguravam os privilégios da aristocracia franca. Ao tornar-se o monarca absoluto mesmo em momentos de relativa paz, o rei recusava sua condição de primus inter paris. Elevando-se sobre a nobreza, ele estabelecia uma diferença entre iguais. 
Quando se trata de seu segundo alvo, Boulainvilliers igualmente recorria aos direitos ilimitados de conquista que a nação franca obtivera com a invasão à Gália, mas, neste caso, é a nobreza - e não o rei - que reivindicava lugar de destaque. Se, para o nobre querelante, francos e gauleses pertenciam a nações diferentes, fazia sentido que ele reivindicasse, no interior dos limites da nação que se unificava, a aplicação de um direito transferido para a relação entre Estados (Koselleck, 1999, p. 41): a lei do mais forte justificava a superioridade da nobreza em relação aos vencidos. Enobrecimentos indiscriminados, portanto, violavam a necessidade de obediência que sempre é devida ao mais forte (Koselleck, 1999, p. 33), pois estabeleciam igualdade entre diferentes.

\section{IV}

Para corroborar seu argumento, Boulainvilliers construiu uma narrativa que informou o desenvolvimento do pensamento liberal francês: em reação ao crescente despotismo real, a defesa das liberdades locais. Em oposição ao universalismo caro ao Estado-nação, a construção de uma visão onírica do passado medieval (Elias, 2001, p. 220) cujas expressões precursoras, a se considerar o estudo de Elias sobre a sociedade de corte, remontam a Joachim du Bellays (1522-1560). Na primeira fase do longo processo de curialização dos guerreiros, ele dava vida ao lamento do fidalgo enclausurado em Paris (Elias, 2001, p. 232). À medida que se confirmava a impossibilidade de se abstrair a corte, reforçava-se a nostalgia de uma pátria campestre e "espontânea" que se contrapunha ao universo de coerções e autocoerções moldados ao redor da realeza. Ou seja, o mesmo processo que punha fim à relativa autonomia das nobrezas provincianas ensejava a idealização desse passado recente. 
Em seu duelo com os romanistas, Boulainvilliers resgatou a seu modo a imagem eclipsada daquela pátria pretérita. Seu pesar pela transformação do patriotismo local em sentimento de fidelidade ao rei ecoava nos seus elogios à monarquia eletiva dos leudes. Tocqueville, na qualidade de derradeiro representante do germanismo na França, retém dessa perspectiva a adesão àquela tripla polaridade: de um lado, em um eixo positivo, descentralização / liberdade / heterogeneidade; de outro, negativo, centralização / igualdade / homogeneidade. Não à toa, em seu estudo sobre as causas da Revolução Francesa, lamentava a decadência daquele patriotismo medieval que tantas maravilhas conseguiu na Idade Média (Tocqueville, 1979, p. 80). A crescente preponderância da capital (Tocqueville, 1979, p. 96-98), Paris, era, para ele, um dos principais sintomas do esmagamento da outrora intensa e variada vida comunal. A centralização administrativa acionada durante o Antigo Regime promoveu a igualdade às custas da liberdade: o pluralismo fora derrotado por

[...] um poder central imenso que atraiu e engoliu em sua unidade todas as parcelas de autoridade e influência antes disseminadas numa porção de poderes secundários [...] por assim dizer espalhados em todo o corpo social (Tocqueville, 1979, p. 56).

Na linhagem liberal que vai de Boulainvilliers a Tocqueville - passando por Montesquieu (Montesquieu, 2000) e Mably (Mably, 1765) -, à potência real é comumente atribuída responsabilidade decisiva pela irrupção da ideologia igualitária; sua ação suplantaria a heterogeneidade derivada dos privilégios aristocráticos. Trata-se de um padrão argumentativo no qual as transformações sociais derivam da iniciativa dos setores socialmente privilegiados - daí a parca atenção que a análise histórica de Tocqueville destina às sedições populares que antecederam a formação da monarquia absoluta (Anderson, 1989, p. 92). Se na narrativa do nobre querelante o rei convertia-se em usurpador dos direitos da aristocracia 
franca, seu conterrâneo do século XIX afirmava, no primeiro volume de $A$ democracia na América, o papel nivelador desempenhado pelos reis franceses (Tocqueville, 1998, p. 9). Aproximadamente duas décadas depois, ele reiterava sua opinião em O Antigo Regime e a Revolução (Tocqueville, 1979, p. 111) - Luís XIV, por exemplo, foi o primeiro a revelar com quanto desprezo era possível tratar as instituições mais antigas e aparentemente melhor assentadas (Tocqueville, 1979, p. 164). Em Lembranças de 1848 ele vai além, radicalizando o argumento: se os reis são os introdutores históricos da igualdade no mundo moderno, são, em última instância, responsáveis pelo desenvolvimento daquela ideologia igualitária que assombra seu relato das Jornadas Revolucionárias: a centralização e o socialismo são produtos do mesmo solo (Tocqueville, 1991, p. 149) ${ }^{4}$.

$\mathrm{E}$ se, na narrativa de Boulainvilliers, a extensão das prerrogativas reais era medida estrangeira à nação franca, igualmente os eventos de 1848 opunham os nacionais a um povo alienígena. Não se tratava mais, evidentemente, do conflito entre aristocratas e Terceiro Estado. Nos momentos imediatamente anteriores à Revolução Francesa, parte expressiva da nobreza aceitara a versão do Abade Mably quanto à suposta gênese dos franceses. A ficção histórica do publicista pré-revolucionário propunha a reconciliação nacional no seio do germanismo: ele estendera a origem germânica ao Terceiro Estado (Mably, 1765, p. 110-111). Assim, estrangeiros, na segunda metade do século XIX, eram as paixões e os desejos dos operários de Paris, sobre os quais triunfara, felizmente, a vontade evidente do povo francês (Tocqueville, 1991, p. 122-123). Daí o aplauso de Tocqueville ao fim das Jornadas: elas livraram a nação da opressão dos operários de Paris e a recolocaram de posse de si mesma (Tocqueville, 1991, p. 173).

${ }^{4}$ Tocqueville assegura que nos reinos seguintes [a Luís XIV] a administração ensinou cada dia ao povo, de uma maneira mais prática e que lhe era mais compreensível, o desprezo que convém ter para com a propriedade privada (Tocqueville, 1979, p. 164). 
Ao contrário de Boulainvilliers, Tocqueville refletia em tempos igualitários. Para ele, a liberdade, na era democrática, não mais se relacionava à garantia de privilégios, mas à defesa das diferenças. Se, como cria, o mundo dos iguais tendia à uniformidade, a descentralização das funções administrativas, ao atribuir aos indivíduos a responsabilidade pela solução de seus problemas locais, surgia como possível antídoto à tirania da maioria. Entretanto, ele reconhecia que as disposições internas das sociedades de mercado tendiam a suplantar a vocação cívica dos indivíduos - e mesmo entre os ainda participativos norte-americanos. Ao fim e ao cabo, o risco que rondava as sociedades modernas assemelhava-se àquele que minou internamente a França pré-revolucionária - há mais de vinte anos, falando de uma outra sociedade, escrevia quase textualmente o que vão ler aqui, dizia ele no prefácio de $O$ Antigo Regime e a Revolução (Tocqueville,1979, p. 47): a concentração das decisões nas mãos do poder central compromete a participação política e o pluralismo, impedindo que as minorias se guiem por seus hábitos e costumes. Se os homens que povoam as eras democráticas abrissem mão, espontaneamente, de participar dos negócios públicos, em troca de um Estado que garantisse a paz pública, estabelecer-se-iam as condições para o despotismo democrático. Se ao Estado só for possível legislar universalmente, à falta de instâncias intermediárias apenas Ihe restará seguir as orientações majoritárias.

A liberdade, para Toqueville, é inimiga de transformações bruscas. Se as revoluções nascem espontaneamente de uma doença geral dos espíritos (Tocqueville, 1991, p. 59), a boa mudança é aquela que penetra lenta e gradualmente nos mœurs de um povo, por meio do exercício da participação política alternativo à servidão. Mas como promover a virtude cívica entre modernos? Seu diagnóstico da experiência norte-americana, 
a se considerar o segundo volume de A democracia na América ${ }^{5}$, aponta para o ocaso da liberdade em face da mercantilização das relações sociais. Note-se que, no livro de 1935, o elogio à América tem como contraponto principal a memória da Revolução: trata-se de perceber como, no Novo Mundo, foi possível gestar uma sociedade simultaneamente calcada em valores igualitários e avessa a sedições. Cinco anos depois, entretanto, Tocqueville privilegia a conexão entre democracia e apatia pública (Melonio, 1993, p. 88). Mas o que nos Estados Unidos se configurava como forte tendência correspondia já à realidade francesa da época: a antiga aristocracia estava vencida, o povo estava excluído, e sob a Monarquia de Julho, comprometida por excessiva homogeneidade de posição (Tocqueville, 1991, p. 39), jazia uma sociedade entorpecida e tranqüila (Tocqueville, 1991, p. 40).

Em ambos os lados do Atlântico, o tempo, por si só, não seria o pedagogo da liberdade. Se no caso francês a inércia cederia brevemente lugar às Jornadas Revolucionárias, a liberdade americana, se não incensada, poderia facilmente comprometer-se nas amarras do despotismo democrático e da tirania da maioria. É verdade que, para ele, o futuro era indeterminado; entretanto, se Tocqueville não proclamava categoricamente qual seria a feição do porvir, jamais abandonou a convicção segundo a qual o governo mais absoluto pode ser combinado com algumas formas da mais extremada democracia de uma maneira que acrescenta a opressão o ridículo de não querer admiti-la (Tocqueville, 1979, p. 83). Esta inclinação natural (Tocqueville, 1979, p. 46) das sociedades igualitárias não poderia ser debelada espontaneamente. Combater a servidão no mundo da igualdade implicava, para Tocqueville, reatualizar a noção

\footnotetext{
$\overline{{ }^{5} \text { No livro de } 1835}$, a verve de Tocqueville é mais descritiva do que analítica. É no segundo volume que ele se preocupa mais detidamente em extrair indicações genéricas da experiência americana quanto à possibilidade de organizar a democracia em termos de leis e costumes. Sintomaticamente, o derradeiro capítulo da obra versa sobre que espécie de despotismo as nações democráticas devem temer (Tocqueville, 2000, p. 387).
} 
aristocrática segundo a qual caberia ao homem comandar a si mesmo (Jasmin, 1997, p. 308). Ele identificava, porém, certa incapacidade dos indivíduos modernos de dispor de tal autonomia. O abismo ente aquilo que julgava necessário e o que lhe soava efetivamente possível fomentava o dilema tocquevilliano: mesmo evitando cair nas amarras do fatalismo, ele percebia que

[...] a liberdade política na sociedade de massas depende de uma práxis e de um conjunto de valores cujas bases tendem a ser destruídas pelo desenvolvimento continuado das disposições internas da própria democracia (Jasmin, 2001, p. 204).

Consequentemente, era preciso fomentar a virtude cívica entre os homens democráticos, daí a necessidade de guias que lhes temperassem os instintos, sugerindo-lhes caminhos que os desviassem da moderna tirania.

Entende-se, assim, seu elogio à magistratura americana: se as instituições comunais eram ocupadas por homens comuns, os legistas compunham uma classe privilegiada. Eles funcionavam como um instrumento de contra-afirmação do poder, um contrapeso da democracia. Características similares às aristocráticas faziam-lhes não perder de vista a consideração que sempre se testemunha às coisas antigas (Tocqueville, 1979, p. 75). Por meio do direito consuetudinário, os legistas atuavam como certa reserva dos costumes, isto é, agiam conservadoramente pautando suas decisões nas de seus predecessores. Ao contrário dos intendentes reais do Antigo Regime, dos homens de letras (Tocqueville, 1979, p. 135-140) ou dos revolucionários jacobinos, os legistas americanos percebiam que a melhor maneira de ensinar aos homens a violar os direitos individuais dos vivos é não levar em conta a vontade dos mortos (Tocqueville, 1979, p. 165).

Se o mundo moderno caracteriza-se, todavia, pelo hiato entre espaço de experiência e horizonte de expectativa (Koselleck, 2006, p. 314), o modelo tocquevilliano poderia obstruir a novidade. O elogio de Tocqueville à Nova Inglaterra decorria, sobretudo, do fato de que, naquela parte da Amé- 
rica, a sociedade, já antiga e desde há muito assentada, pôde formar máximas e hábitos [...]. Por isso, vemos a democracia na Nova Inglaterra fazer escolhas melhores que em todo o resto do país. Em oposição, ele assinalava que, à medida que se rumava em direção ao Sul dos Estados Unidos, onde o vínculo social é menos antigo [...], os talentos e as virtudes se tornam cada vez mais raras entre os governantes (Tocqueville, 1998, p. 234).

Dito de outro modo, a ênfase que atribuía Tocqueville ao desenvolvimento lento e gradual dos hábitos e costumes tornava-o, por um lado, árduo defensor das antigas leis da sociedade contra os inovadores (Tocqueville, 1991, p. 122), ou seja, da permanência daquelas diferenças consolidadas pela obra do tempo, pela tradição; por outro, refratário às inéditas diferenças que lutavam pelo protagonismo na arena pública em meados do século XIX.

Resgatar seu elo com a perspectiva germanista elaborada durante a Querela, e aqui personificada em Boulainvilliers, auxilia a compreender as razões que faziam Tocqueville crer que, se as classes mais poderosas abrissem mão da tarefa de educar a democracia, ela seria entregue aos seus instintos selvagens (Tocqueville, 1998, p. 12). Ele reconhecia a velocidade com a qual a igualdade invadira o Ocidente, e durante certo tempo cria ainda ser possível conduzi-la, mas suas esperanças sucumbiram durante as jornadas revolucionárias de 1848. Havia-se assegurado às pessoas pobres que o bem dos ricos era de alguma maneira produto de um roubo cujas vítimas eram elas e foi-lhes dito que a desigualdade de fortunas era tão contrária à moral e à sociedade quanto à natureza (Tocqueville, 1991, p. 150). Desta feita, a rafameia galo-romana desafiava definitivamente a tradição franca ao contestar o "fundamento de nossa ordem social" (Tocqueville, 1991, p. 95), o direito de propriedade. Em outros termos, a democracia opunha-se ao liberalismo.

Nem privilégios, nem diferenças - quando o futuro lhe aponta para o comprometimento da liberdade nas teias do nivelamento universal, o 
aristocrata normando opta pelo silêncio: mesmo testemunha, mesmo ator, ele faz questão de se retirar do espetáculo (Braudel, 1991, p. 22). Evidenciar sua continuidade em relação à tradição germanista inaugurada por Boulainvilliers permite que se compreenda o repúdio de Tocqueville ao poder popular e, consequentemente, os obstáculos que sua sociologia política impõe às democracias contemporâneas.

\section{Referências}

1. ANDERSON, P. Linhagens do Estado absolutista. São Paulo: Brasiliense, 1989.

2. ARENDT, H. Origens do Totalitarismo: anti-semitismo, imperialismo, totalitarismo. São Paulo: Companhia das Letras, 1989.

3. ARON, R. As Etapas do Pensamento Sociológico. Brasília: Ed. Universidade de Brasília, 1987.

4. BERLIN, I. Quatro Ensaios sobre a Liberdade. Brasília: Ed. Universidade de Brasília, 1981.

5. BESNIER, J.-M. Tocqueville et les associations. In: L'Actualité de Tocqueville (Actes du Colloque de Saint-Lô 5septembre 1990). Caen: Centre de Philosophe Politique et Juridique de l'Université de Caen, 1991, p. 73-82.

6. BOBBIO, N. et al. Dicionário de Política. Brasília: Ed. UNB, 1991.

7. BOULAINVILLIERS, H. Histoire de l'Ancien Gouvernement de la France: avec XIV Lettres Historiques sur les Parlements ou États Généraux. 1727. (Tomo 1). Disponível em: $<$ http://visualiseur.bnf.fr/Visualiseur?Destination=Gallica\&O= NUMM-87689>.

8. BRAUDEL, F. Prefácio. In: TOCQUEVILLE, A. Lembranças de 1848: as Jornadas Revolucionárias em Paris. São Paulo: Cia. Das Letras, 1991, p. 17-30.

9. CONSTANT, B. Da Liberdade dos Antigos comparada à dos Modernos. In: ZARKA, Y. (org.). Filosofia Política 2. Porto Alegre: L\&PM, 1985. p. 9-25.

10. ELIAS, Norbert. A Sociedade de Corte: investigação sobre a sociologia da realeza e da aristocracia de corte. Rio de Janeiro: Jorge Zahar, 2001.

11. FEBVRE, Lucien. Au cœur religieux du XVlème siècle. Paris: Le livre de poche, 1999.

12. FOUCAULT, M. Em Defesa da Sociedade: curso no Collège de France (19751976). São Paulo: Martins Fontes, 2002. 
13. FURET, F. L'atelier de I'Histoire. Paris: Flammarion, 1982.

14. FURET, F. L'importance de Tocqueville aujourd'hui. In: FURET, F. L'Actualité de Tocqueville (Actes du Colloque de Saint-Lô 5septembre 1990). Caen: Centre de Philosophe Politique et Juridique de I'Université de Caen, 1991. p. 135-145.

15. FURET, F. Pensar a Revolução Francesa. Lisboa: Edições 70, 1988.

16. FURET, F., OZOUF, M. (org.). Dicionário Crítico da Revolução Francesa. Rio de Janeiro: Nova Fronteira, 1989.

17. GOLDMANN, Lucien. Ciências humanas e filosofia. São Paulo: DIFEL, 1986. 18. HENSHALL, Nicholas. The myth of absolutism. Londres: Longman, 1992.

19. HOBSBAWN, E. A era dos extremos: o breve século XX. São Paulo: Cia. das Letras, 2000.

20. JARDIN, A. Historia del Liberalismo Político: de la crisis del Absolutismo a la Constitución de 1875. Cidade do México: Fondo de Cultura Económica, 1989.

21. JASMIN, M. Alexis de Tocqueville: a historiografia como ciência da política. Rio de Janeiro: Access, 1997.

22. JASMIN, M. As Américas de Tocqueville: a comunidade e o auto- interesse. In: SOUZA, J. (org.). Democracia Hoje: novos desafios para a Teoria Democrática contemporânea. Brasília: Ed. Universidade de Brasília, 2001. p. 201-211.

23. KOSELLECK, R. Crítica e Crise: uma contribuição à patogênese do mundo burguês. Rio de Janeiro: Eduerj; Contraponto, 1999.

24. KOSELLECK, R. Futuro Passado: contribuição à semântica dos tempos históricos. Rio de Janeiro: Contraponto, 2006.

25. MABLY, G. Observations sur I'histoire de France. 1765. Disponível em: < http:// visualiseur.bnf.fr/CadresFenetre? $\mathrm{O}=\mathrm{NUMM}-882 \sim \& M=$ pageseule $\& \mathrm{Y}=$ Texte $>$.

26. MADISON, J.; HAMILTON, A.; JAY, J. Os Artigos Federalistas: 1751-1836. Rio de Janeiro: Nova Fronteira, 1993.

27. MAZOWER, M. Continente sombrio: a Europa no século XX. São Paulo: Cia. das Letras, 2001.

28. MEINECKE, F. El historicismo y su génesis. Cidade do México: Fondo de Cultura Económica, 1982.

29. MELONIO, F. Tocqueville et les Français. Paris: Aubier, 1993.

30. MONTESQUIEU, C. O espírito das leis. São Paulo: Martins Fontes, 2000.

31. REIS FILHO, D. A. O Manifesto e a Revolução em 1848. In: O Manifesto Comunista 150 Anos depois. Rio de Janeiro: Contraponto, 1998. p. 75-100. 
32. RODRIGUEZ, R. V. Tocqueville au Brésil. La Revue Tocqueville, Toronto, v. 20, n. 1, p. 147-176, 1999.

33. SANTOS, B. Pela mão de Alice: o social e o político na pós-modernidade. Porto: Afrontamento, 1997.

34. SIEYES, E. A Constituinte Burguesa: Que é o Terceiro Estado? Rio de Janeiro: Liber Júris, 1988.

35. TOCQUEVILLE, A. A democracia na América: leis e costumes. São Paulo: Martins Fontes, 1998.

36. TOCQUEVILLE, A. A democracia na América: sentimentos e opiniões. São Paulo: Martins Fontes, 2000.

37. TOCQUEVILLE, A. Lembranças de 1848: as Jornadas Revolucionárias em Paris. São Paulo: Cia. das Letras, 1991.

38. TOCQUEVILLE, A. O Antigo Regime e a Revolução. Brasília: Editora Universidade de Brasília, 1979.

39. VOLLRATH, E. O Despotismo Ocidental. Filosofia Política, n. 3, p. 131-145, 1986.

Recebido em: 19/10/2011

Aceite final: 23/12/2011 